\title{
Literature Review on Furfural Production from Lignocellulosic Biomass
}

\author{
Grazielle Machado1 ${ }^{*}$, Sabrina Leon1, Fernando Santos' ${ }^{1}$, Rogério Lourega ${ }^{2}$, Jeane Dullius², \\ Maria Elizabete Mollmann², Paulo Eichler ${ }^{1}$ \\ ${ }^{1}$ Study Center in Biorefinery, State University of Rio Grande do Sul, Porto Alegre, Brazil \\ ${ }^{2}$ Institute of Petroleum and Natural Resources, Pontifical Catholic University of Rio Grande do Sul, Porto Alegre, \\ Brazil \\ Email: "graziellediasmachado@gmail.com
}

Received 22 January 2016; accepted 18 March 2016; published 21 March 2016

Copyright (C) 2016 by authors and Scientific Research Publishing Inc.

This work is licensed under the Creative Commons Attribution International License (CC BY).

http://creativecommons.org/licenses/by/4.0/

(c) (i) Open Access

\begin{abstract}
The use of renewable sources for obtainment of chemicals, biofuels, materials and energy has become each time larger due to environmental, political and economical problems of non-renewable energies utilization. Among several products that can be obtained from lignocellulosic biomass, which is a renewable source, there is furfural, a chemical from which many other value added chemical products can be obtained. The main route for furfural production consists of an acid hydrolysis of hemicelluloses present in lignocellulosic biomass to obtain xylose, which goes through a dehydration reaction to produce furfural. Due to the presence of an aldehyde group and a conjugated system of double bounds, furfural can go through several reactions, allowing the production of a range of value added products. In this sense, this article performs a review about mechanisms of furfural production from lignocellulosic biomass, highlighting its chemical properties which enable its utilization in different industrial applications of economic interest.
\end{abstract}

\section{Keywords}

Furfural, Xylose, Lignocellulosic Biomass, Biorefinery

\section{Introduction}

Because of frequent crisis in petroleum supply, possibility of its scarcity, prices instability and negative effects to the environment, the interest in alternative energy sources has increased in the last years [1]. Global warming brought the discussion about corporations and countries social responsibility in adopting feedstocks which gen-

\footnotetext{
${ }^{*}$ Corresponding author.
}

How to cite this paper: Machado, G., Leon, S., Santos, F., Lourega, R., Dullius, J., Mollmann, M.E. and Eichler, P. (2016) Literature Review on Furfural Production from Lignocellulosic Biomass. Natural Resources, 7, 115-129. 
erate clean energy. The use of clean energies can be a solution for shortage in petroleum supply, since they are generated from natural cycles, do not cause alterations in the planet thermal balance, and are profitable, because they offer the companies the possibility of negotiating in the carbon credits market [2] [3]. Brazil has invested in different renewable energy sources, becoming the fourth country in the world in energy production from renewable sources and even being the seventh country in total energy demand in the world, due to its great participation in renewable sources, the country occupies the twelfth position in carbon dioxide emissions [4]. Starting on 1970 along with Brazilian National Biofuel Program (Proalcool), ethanol production has stood out in Brazil. Nowadays, Brazilian ethanol produced from sugarcane has the lower cost of production and higher yield of liters per hectare of product. The country's annual capacity of production is 1.5 billions of liters of ethanol [5].

Ethanol from sugarcane juice is the only fuel capable of attending the growing world demand for renewable and low-cost energy. However, the development of economically feasible processes which use lignocellulosic biomass as source of carbohydrates for alcoholic fermentation has been studied. Lignocellulosic biomass is any organic matter that is available in a renewable basis which includes energy crops, agricultural residues, aquatic plants, wood and wood residues as well as other waste materials [6]. A great interest in the utilization of agriculture and forestry residues in the obtainment of renewable fuels, such as ethanol, has been observed. Despite of the huge amount of ethanol production already existent, its production from alternative sources can be interesting if associated with already consolidated industrial processes. An interesting byproduct which can be produced along with ethanol is furfural [7]-[10]. Furfural, a chemical similar to 5-hydroxymethylfurfural, is one of the furan derivatives produced from the hemicellulosic fraction of lignocellulosics, which is considered a promising commodity bio-based chemical because of the possibility of its use in the production of several products as antacids and fertilizers [11] [12]. From the economic point of view, this method produces approximately 2.042 million kg of ethanol and 1.47 million $\mathrm{kg}$ of furfural annually. It is estimated that a fixed capital of US\$ 1.388 million and US\$ 295 thousand in equipment result in a gross profit of US\$ 0.414 million per year and an operating cash flow of US\$ 0.174 thousand [9]. In a year, 250,000 tons of furfural are produced, which is applied as solvent or starting material for preparation of other organic solvents such as furfuryl alcohol and tetrahydrofuran [13].

Furfural is one of the platform chemicals which can be used as a starting reagent to produce other high value added products and which can be produced from different lignocellulosic residues, such as the ones from agriculture activities. It is a shining and uncolored oil that when exposed to oxygen from air undergoes an oxidation, changing its color [14] [15]. The production of some important furfural derivatives, such as furfuryl alcohol and tetrahydrofurfuryl alcohol has great interest once they can be used in several applications [16]. Thus, furfural production has attracted a lot of attention in the last years.

Hemicelluloses, which are the main feedstock for furfural production, are the second polysaccharide most abundant in nature, composing around 20\% - 35\% of lignocellulosic biomass [1]. Nevertheless, in cellulose and paper industries these polymers have not been used effectively. Biorefinery technology shows that it is possible to separate hemicelluloses from lignocellulosic biomass and produce high value added products, along with the use of cellulose in paper production [17]. Besides that, the yield of solid biomass hydrolysis is very low because of mass transfer limitations. Available studies about furfural production from aqueous hemicelluloses solutions are sparse, being necessary more studies to prove the viability of using this material for furfural production [18].

One of the main advantages of lignocellulosic biomass as feedstock in furfural production is the fact that these sources are renewable. These biomasses, such as corncob, sugarcane bagasse, rice husk and wheat bran are the major sources used for furfural obtainment, considering that they are rich in hemicelluloses and are regularly available in huge amounts [19] [20]. Sugarcane bagasse and corncob are the two materials most used for furfural production being responsible for more than $98 \%$ of all furfural produced [14]. These feedstocks are part of a sustainable productive process, have a great availability in nature, and their use do not harm the environment, attribute of considerable importance in contemporaneous world.

In this context, lignocellulosic biomass, through biorefinery, presents vast possibilities for research and utilization in the production of several bioproducts such as furfural, which can be used in diverse applications and used in the production of other important chemicals. Therefore, this article has the purpose of analyzing applications and different production methods for furfural from lignocellulosic biomass. A review about the chemical composition of lignocellulosic biomass along with the potential chemical, thermochemical and biochemical processes of lignocellulosic biomass conversion in bioproducts in the biorefinery context is accomplished. Routes of furfural production from biomass are exposed. Several furfural applications are highlighted, as well as furfur- 
al properties and economic aspects.

\section{Biomass and Biorefineries}

In general, lignocellulosic biomass can be defined as a natural resource that can be used for energy production or more elaborated bioenergetic forms for final use [21]. Lignocellulosic biomass is a promising feedstock for biofuels, bioenergy, biomaterials and biochemicals production because of its abundance, availability and renewable character [1] [22] [23].

The major biomass sources are energetic crops and agriculture, forestry, industrial and urban residues. Energetic crops are generally densely cultivated, have high productivity and short rotation, such as hybrid willow, sunflower and barley. Agriculture residues are composed of stalks and leaves which are not collected in commercial crops, such as sugarcane bagasse, rice straw and saccharine sorghum bagasse. Forestry residues refer to biomass not collected from logging sites, as well as biomass resulting from forest management operations. Industrial and urban residues include solid residues, sewage sludge and industrial residues [1] [6]. Sources of plant biomass, such as agriculture residues and energetic crops, are excellent alternatives for feedstocks once they present high biomass productivity, high sugar content, are easy to grow having extensive cultivation in short period of time, are tolerant to drought, to high temperatures, to floods and saline stress, as well as have low soil demands [22].

Lignocellulosic biomass is composed of three major constituents: cellulose, hemicelluloses and lignin, which form a structure of cellulose microfibrils incorporated in a matrix of hemicelluloses and lignin. Lignocellulosic minor compounds are extractives, which are low molecular weight organic compounds, and ashes, which are inorganic compounds. Biomass chemical composition varies a lot according to type of plant, cultivation conditions and plant age, as exposed on Table 1 [24].

Cellulose is the natural polymer of greatest natural occurrence in the world. It is a homopolymer formed by $\beta$-cellobiose repeating units, a disaccharide composed by two D-glucose molecules, linked by $\beta$-1,4glycosidic bonds (Figure 1).

Glucose units in $\beta$-cellobiose are inverted in relation to its neighbor molecules, leading to the formation of a linear glycan chain. Chains linearity enables the proximity of molecules, facilitating formation of intra- and intermolecular hydrogen bonds, and consequently forming microfibrils, which are long and compact semi-crystalline structures. Since microfibrils present high length, some regions become unordered and amorphous. The characteristics which grant a crystalline structure to cellulose provide high resistance to tension, making cellulose insoluble in water and in a large group of other solvents [10] [22] [25].

Table 1. Chemical composition of different types of lignocellulosic biomass.

\begin{tabular}{cccc}
\hline Lignocellulosic biomass & \% Cellulose & \% Hemicelluloses & \% Lignin \\
\hline Sugarcane bagasse & 40 & 24 & 25 \\
Corn straw & 40 & 25 & 17 \\
Corncob & 39 & 35 & 15 \\
Corn fiber & 15 & 11 & 30 \\
Cotton stem & 31 & 25 & 12 \\
Rice straw & 35 & 12 & 18 \\
Soy straw & 25 & $35-39$ & $8.3-12.5$ \\
Wheat bran & $10-15$ & 21.2 & 23.4 \\
Wheat straw & 38.2 & 36 & 16 \\
Wheat chaff & 38 & $35-50$ & $10-30$ \\
Grass & $25-40$ & 18.6 & 26.4 \\
Softwood (pine) & 44.7 & 21.9 & 27.7 \\
Paper residues & 44.6 & 13 & 11 \\
\hline
\end{tabular}

a. Source: Yang, 2013 [24]. 
Hemicelluloses are complex heteropolysaccharides composed by D-glucose, D-galactose, D-mannose, D-xylose, L-arabinose, glucuronic acid and 4-O-methyl-glucuronic acid (Figure 2). These polymers are amorphous, highly substituted with acetic acid and present branches which easily interact with cellulose, providing stability and flexibility to the aggregate.

Monosaccharides connect to each other by $\beta-1,4$ and $\beta-1,3$ glycosidic bonds. The most abundant hemicelluloses structural block in hardwoods and agricultural plants is xylan, a polymer formed by xylose units. While, in softwood, the most abundant structural block is glucomannan, a polymer with a linear chain of D-mannose and D-glucose connected by $\beta$-1,4 glycosidic bonds and some branches. Some of the sugars present in hemicelluloses associate with lignin, forming carbohydrate-lignin complexes, making enzymatic cleavage of lignocellulosic residues more complicated [6] [10] [22].

Lignin is an amorphous heteropolymer which consists of three different phenylpropanoid units: p-coumaryl alcohol, coniferyl alcohol and sinapyl alcohol (Figure 3).

Composition and structure of lignin components is not uniform and varies according to the type of biomass. In softwood lignin, the main structural block is coniferyl alcohol along with small amounts of coumaryl alcohol (Figure 4). In hardwood, lignin is composed by both coniferyl and sinapyl alcohols along with a small amounts of p-coumaryl alcohol [6] [10] [26].

Intermolecular interactions between the three major components of lignocellulosic biomass, which are cellulose, hemicelluloses and lignin, determine biomass recalcitrant structure (Figure 5). Cellulose microfibrils crys-

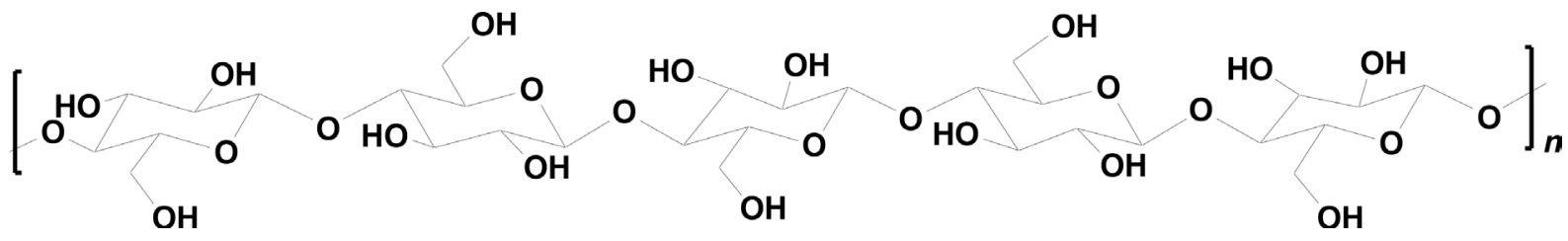

Source: Santos, 2012 [10]

Figure 1. Schematic representation of cellulose molecule.

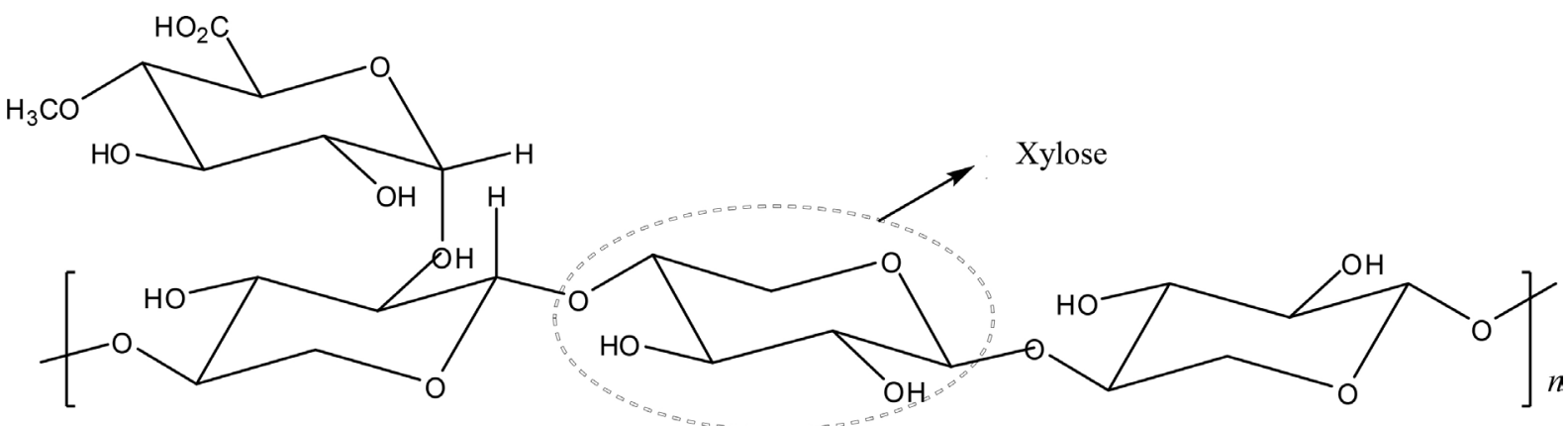

Source: Santos, 2012 [10]

Figure 2. Schematic representation of hemicelluloses.<smiles>OC/C=C/c1ccc(O)cc1</smiles>

p-coumaryl alcohol<smiles>COc1cc(/C=C/CO)ccc1O</smiles>

coniferyl alcohol<smiles>COc1cc(/C=C/CO)cc(OC)c1O</smiles>

sinapyl

alcohol

Figure 3. Lignin primary precursors. 


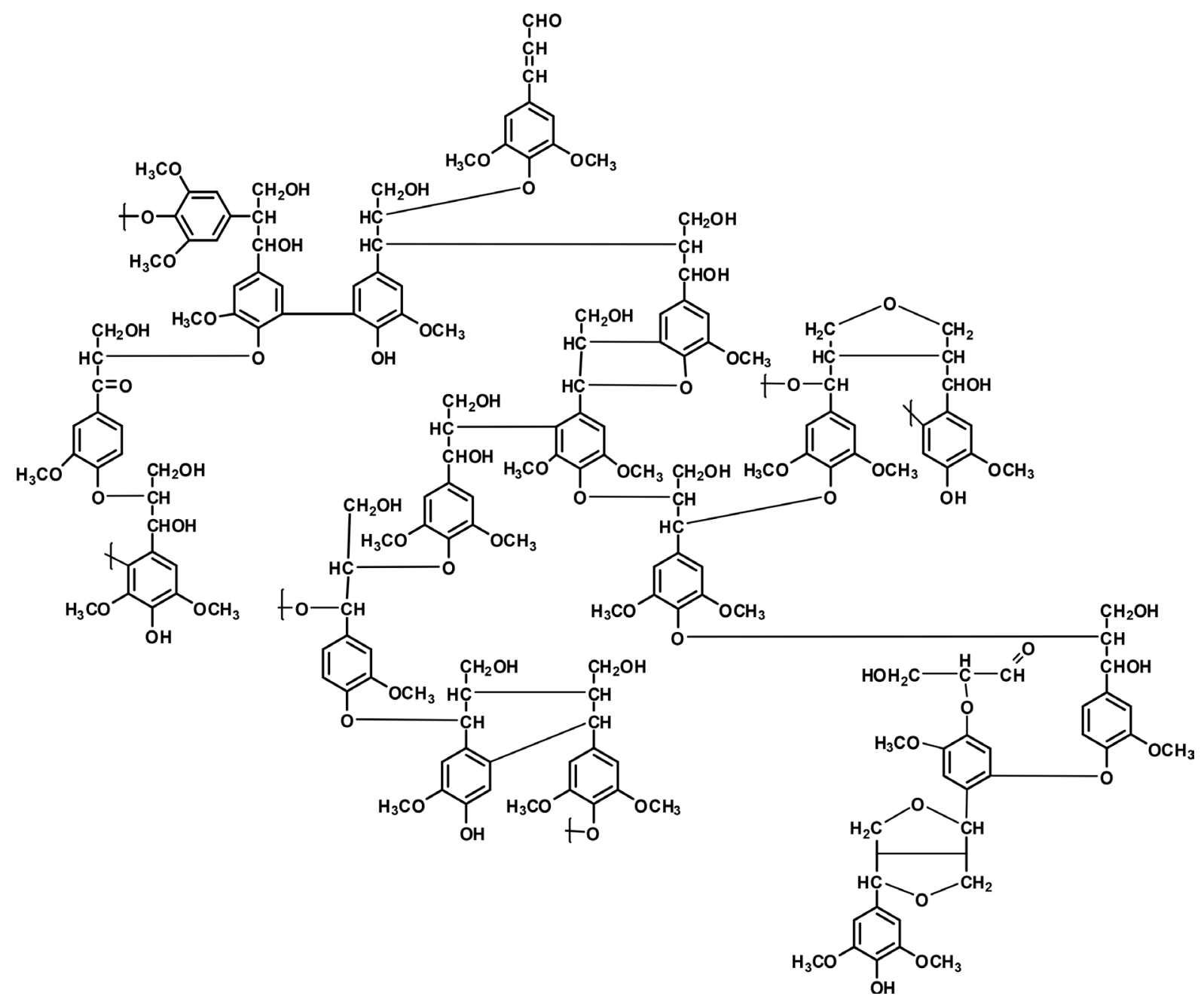

Source: Santos, 2012 [10]

Figure 4. Schematic representation of eucalyptus lignin.

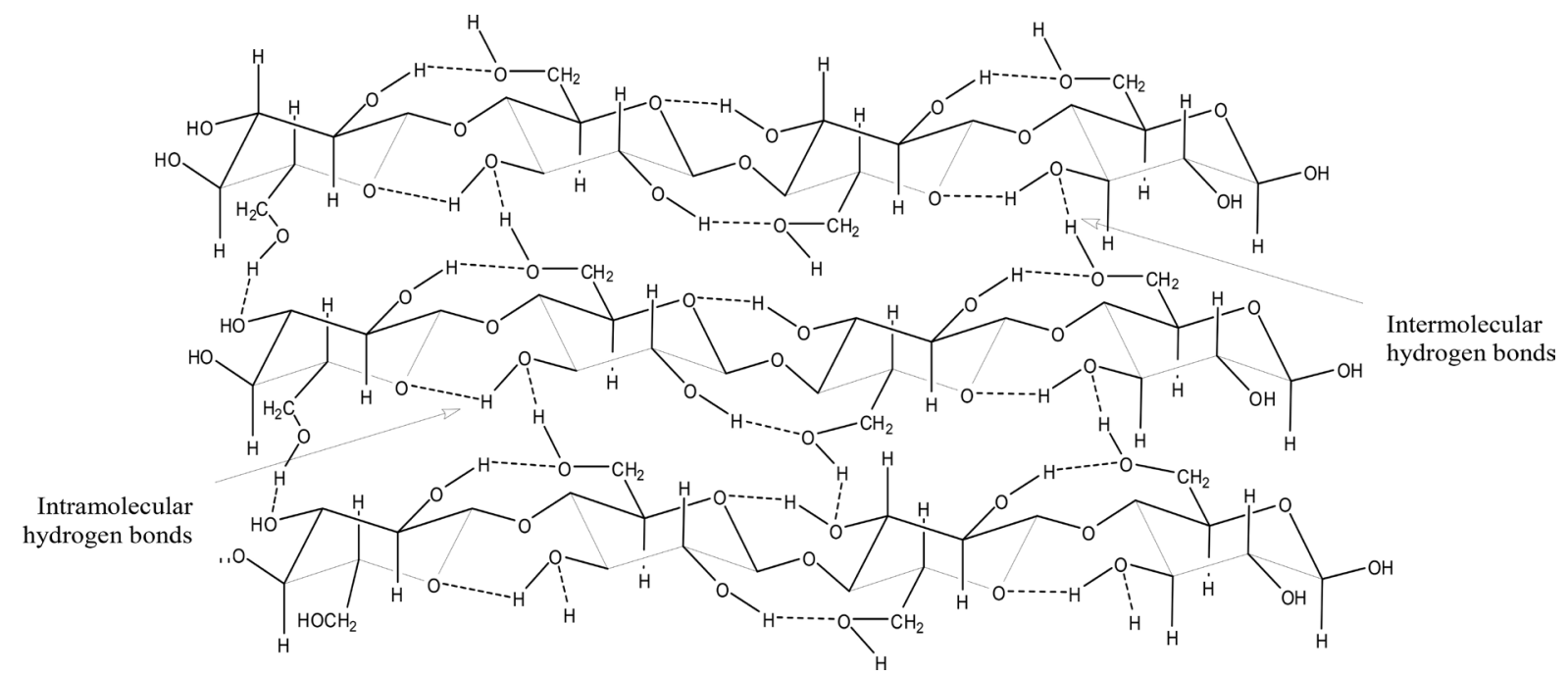

Source: Santos, 2012 [10]

Figure 5. Cellulose supramolecular hydrogen bonds. 
talline structure in the cell wall make it resistant to chemical and biological hydrolysis. Besides that, the coverage of microfibrils by lignin, hemicelluloses and cellulose amorphous regions also difficult the access of catalytic enzymes to microfibrils.

Thus, liberation of polysaccharides as source of fermentable sugars for production of different bioproducts and energetic forms is one of the crucial and limiting steps of the process. Due to structural recalcitrance, the use of lignocellulosic biomass needs a pretreatment step for its efficient fractionation [1] [24] [27]-[29]. Utilization of renewable biomass as feedstock in conversion, treatment and processing processes for obtaining high value added products gave rise to the term biorefinery. A biorefinery has as objective the production and generation of a large variety of products using lignocellulosic biomass as feedstock through a combination of conversion technologies. In a biorefinery, the processes of biomass conversion may be integrated in such a way that a range of biofuels, bioenergy, biomaterials and biochemicals are produced together. In this sense, it is sought to aggregate value and create new products from materials previously treated as residues, and which can be treated as byproducts. When producing this large variety of products, biorefineries can explore biomasses maximum potential and aggregate the highest possible value to these materials, thus increasing profitability, reducing energetic demand and reducing emissions of gases that cause greenhouse effect. Besides that, the large range of products reduce the dependence on the production of only one product, increasing the sustainability of using biomass and reducing the competition existing between the use of biomass for food or fuels [30] [31].

Biorefineries can be classified according to the type of platform used, type of products to be produced, feedstock and conversion processes. Among the products there are basically five types: energy, chemical inputs, biofuels, materials and chemical products. A huge variety of types of biomass can be used in biorefineries such as energetic crops, residues from food crops, agribusiness, forests and industries. Concerning types of conversion process, there are biochemical processes such as, fermentation and enzymatic conversions; thermochemicals, like pyrolysis and gasification; chemicals as acid hydrolysis and transesterification; and mechanicals, such as fractionation and pressure [1] [31].

Thus, biorefineries are an excellent alternative to replace products and processes based on non-renewable feedstock because they are based on biomass utilization. This model is quite versatile and economically attractive, due to the products which can be obtained and the different value added. However, there are challenges to be overcome to make biorefineries feasible. Since the largest part of biorefinery processes still are in the development phases it is needed to seek means of achieving maximum efficiency in the processes, as well as the expansion of integration between the conversion platforms. Another challenge is the fact that chemical composition of lignocellulosic biomass varies considerably among different species, as wells as in the same species due to cultivation conditions, being necessary particular studies for each type of biomass to be used. And finally, because of biomass recalcitrant structure, a pretreatment step is usually needed, making it one of the limiting steps of the process due to the high impact on the final product cost [32]-[34].

\section{Furfural Production}

Xylans, one of the types of hemicelluloses present in abundance in lignocellulosics, are composed mainly by pentoses and generally are the major constituents of hemicelluloses in grasses and woods. Lately, studies focusing in the conversion of xylans to bioenergy, chemicals and biomaterials have received a lot of attention in the context of biorefineries. Among the products which can be obtained from pentoses, there is furfural, which is a promising alternative, since it is a versatile compound that can be used in the synthesis of several important chemicals, such as furan and furfuryl alcohol, and it is vastly used in several applications in refining oil, plastics production, pharmaceutical and agrochemical industries [35].

Nowadays there is not a synthetic route for furfural production, so it is exclusively produced from acid hydrolysis and dehydration of pentose, mainly xylose, this way it is possible to produce it from hemicelluloses (Figure 6 and Figure 7). There are two processes for furfural production, one that happens in an only step and the other which happens in a two-step process. In the one-step process, depolymerization of pentosans in xylose by acids and dehydration to furfural occurs simultaneously. In the two-step process, dissolution and depolymerization of pentosans occur in mild condition, followed by dehydration of xylose to furfural [36]-[38].

Hemicelluloses hydrolysis stage occurs in four steps (Figure 8): 1) protonation of oxygen bond of the ether leading to the formation of a trivalent oxygen; 2) cleavage of the oxygen bond forming a carbocation in one side and a hydroxyl group in the other side; 3) reaction of carbocation with water; 4) $\mathrm{H}^{+}$liberation and formation of a 


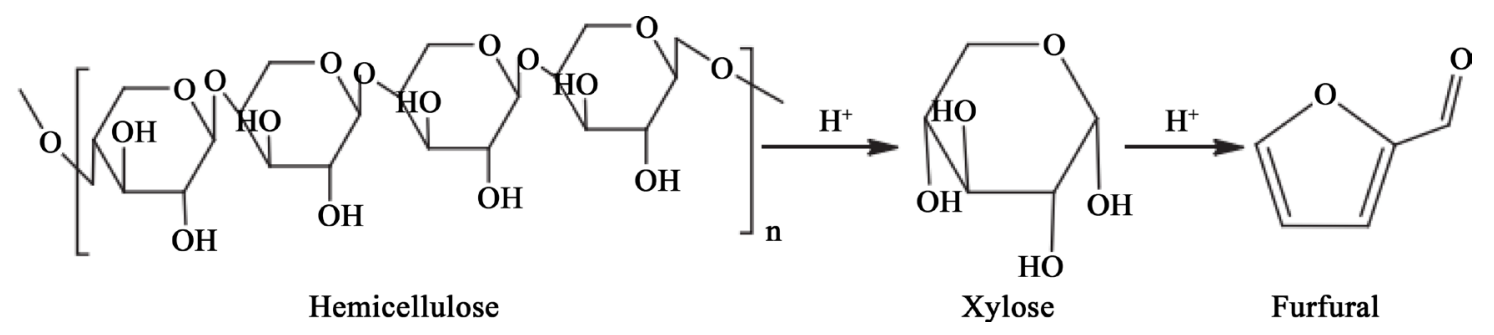

Source: Yan, 2014 [11].

Figure 6. Furfural production from hemicelluloses.

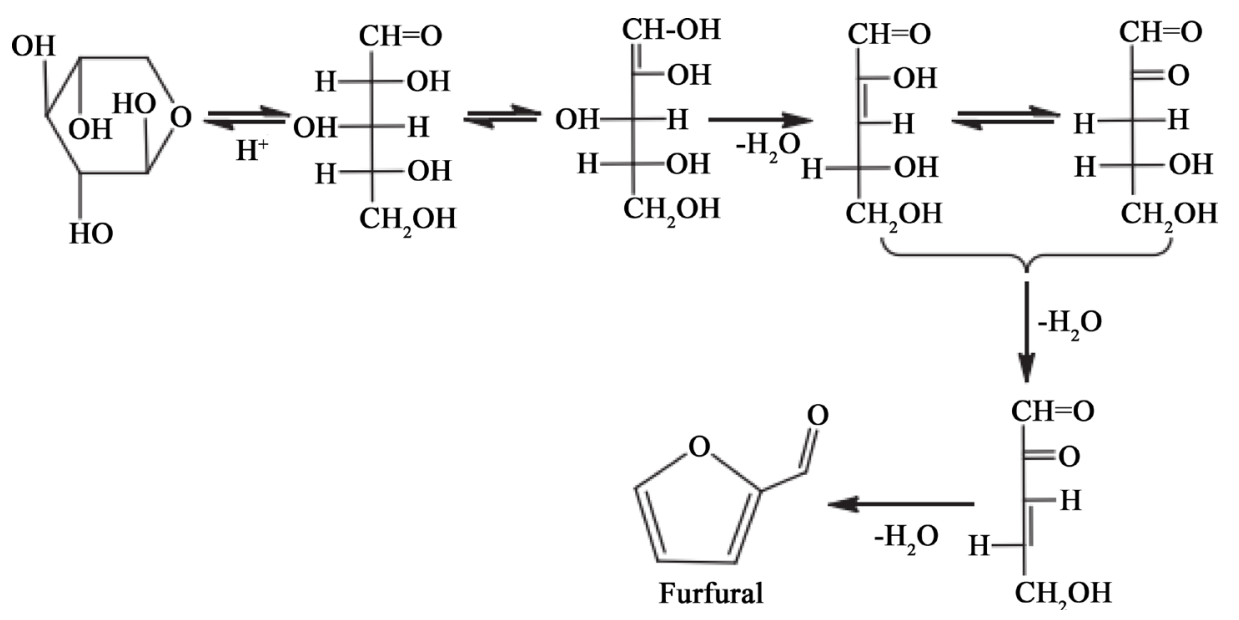

Source: Yan, 2014 [11].

Figure 7. Dehydration of pentoses for furfural production.

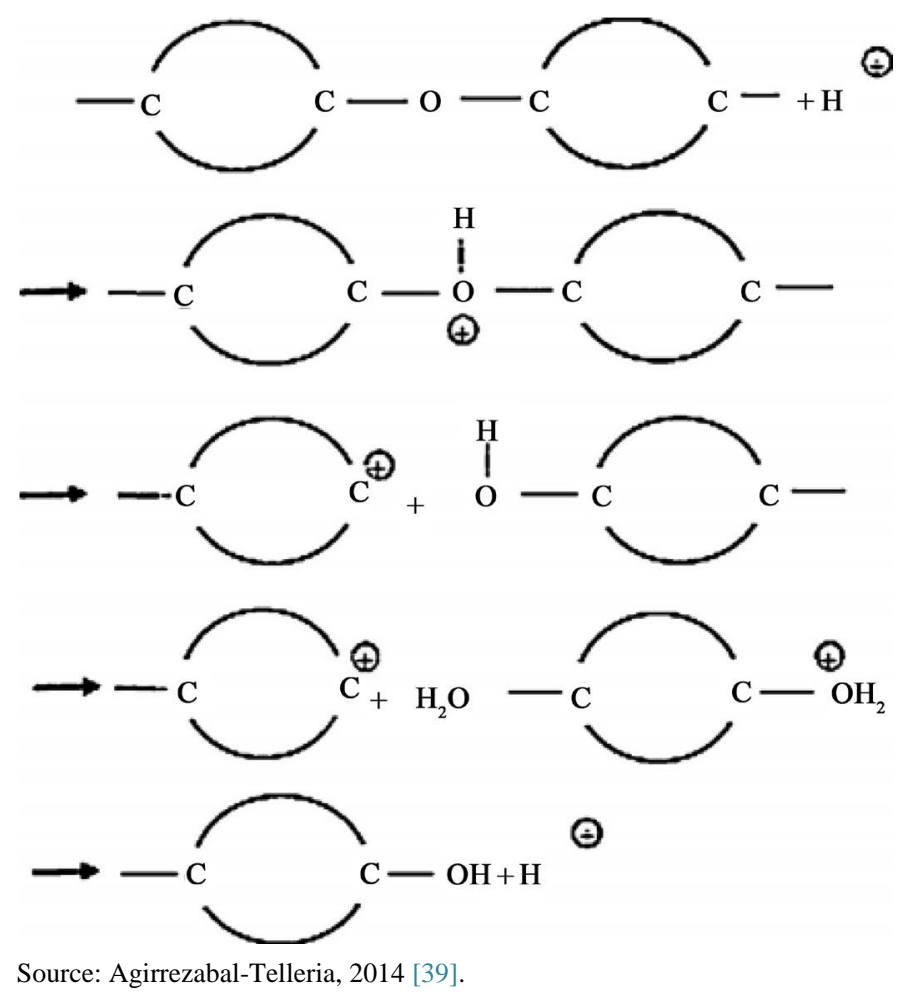

Figure 8. Steps of hemicelluloses hydrolysis to xylose. 
hydroxyl group. On the other hand, cyclodehydration for furfural formation occurs via two subsequent eliminations type 1,2- and a elimination type 1,4-, respectively. In the first step, when $\mathrm{H}+$ attacks a non-bonding electron pair of a hydroxyl oxygen bound to a carbon atom, a trivalent oxygen atom positively charged is created. Since oxygen is more electronegative, the charge passes to the neighbor carbon causing the cleavage of the carbon-oxygen bond, and leading to the liberation of a water molecule. In this situation, two electron from C-X bonds are attracted to form a double bond $\mathrm{C}=\mathrm{C}$. During this step, the ring is opened and the freed hydrogen seeks another non-bound pair of electrons. In the same way as in the first elimination, another water molecule is liberated and another double bond $\mathrm{C}=\mathrm{C}$ is established. In the last elimination type 1,4, oxygen trivalent ion do not create another $\mathrm{C}=\mathrm{C}$ bond, but closes the open ring due to the fact that atoms which participate in double bonds form planar structures characterized by bond angles of $120^{\circ}$, leading to furfural formation. Finally, liberation of $\mathrm{H}+$ ends the process [39].

Barbosa (2014) [36] investigated furfural production from corn stalk, sugarcane bagasse and eucalyptus wood using different concentrations of some types of mineral acids $\left(\mathrm{HCl}, \mathrm{H}_{2} \mathrm{SO}_{4} \mathrm{e}_{3} \mathrm{PO}_{3}\right)$. They also investigated the potential of using auto-hydrolyzates from auto-hydrolysis kraft process done in eucalyptus wood. The auto-hydrolyzate extracted in the process first phase is rich in xylose oligomers and monomers, which have potential for furfural production. Hydrochloric acid was the one which presented higher yield, efficiency and productivity of furfural. The most promising biomass was corn stalk, however it was also proved that the use of eucalyptus liquor from auto-hydrolysis is feasible, what had never been used before as source of xylose for furfural production.

Kaur (2015) [40] studied the use of pre-hydrolysis liquor from kraft process for furfural production. Hemicelluloses in the liquor were concentrated through membrane separation and converted to furfural using reactors in monophasic and biphasic systems, proving the feasibility of the process. Baktashet (2015) [41] also used the pre-hydrolysis liquor from kraft process as feedstock for furfural production. Besides the membrane separation and concentration also accomplished by Kaur (2015) [40], Baktashet (2015) [41] also employed adsorption in activated carbon and treatment with ionic exchange resins as pretreatments to increase furfural production yield, contribute to lignin removal, facilitate the process and minimize side reaction. Li (2016) [42] investigated the effect hemicelluloses characteristics of corn stalk in alkaline medium for furfural production. It was found that a higher amount of xylose, lower number of branches, higher polydispersity and crystallinity of hemicelluloses contributed for furfural production.

Furfural is commercially produced in batch or continuous processes using mineral acids as catalysts, even though this process presents drawbacks as corrosion, difficult product and catalysts recuperation from reaction mixture and risks to health and the environment. Aiming to optimize furfural production processes, several studies have been done involving the use of new types of catalysts in monophasic and biphasic reaction systems. It was investigated the use of different solvents to replace water, as ionic liquids, organic solvents and supercritical fluids in monophasic systems, while in biphasic systems combinations of water/organic solvents were tested. Among many organic solvents tested in biphasic systems that can increase the yield and selectivity of furfural, 2-methyltetrahydrofuran has been showing to be a good option. This compound can be prepared from lignocellulosics and easily separated from the aqueous phase due to its low solubility in water, stability in acid and alkaline conditions, low toxicity, easy recycling and environmentally friendly characteristics, because it is a product from green chemistry. Besides improving reaction system, it has been studied the use of catalysts which do no harm so much the environment as the mineral acids. One of the possible substitutes to mineral acids are metallic chlorides, which have shown improvement in furfural rate of formation, and it was proved that both chloride ions and metallic cations are responsible for furfural production [35] [43].

In order to replace the use of mineral acids in furfural production, in recent years, many acid solid catalysts were developed and applied successfully in the reaction for furfural preparation. One of the problems about using solid catalysts is when the reaction solvent is too polar and highly protic, as water for example, because only a few acid solids can keep the desired acidity due to interactions between solvent-surface by solvation. One of the types of acid solids whose properties are tolerant to presence of water is the one which has niobium in its composition, as niobium pentoxide hydrate, $\mathrm{Nb}_{2} \mathrm{O}_{5} \cdot \mathrm{nH}_{2} \mathrm{O}$, called niobic acid. Nevertheless, the use of this type of catalyst decreases selectivity and yield of desired products, due to byproducts formation, as humins, which deposit on the catalyst surface decreasing its activity. Molina (2015) [44] compared activity and stability of using pure niobium and niobium supported on silica-zirconia and proved that immobilization of niobic acid makes it a more stable catalyst, which can be recycled and operated in continuous process during the reaction, yet ac- 
tivity presented is lower when compared to pure niobium.

Zeolites, which are among the most studied acid solid catalysts, are microporous crystalline inorganic aluminosilicates highly structured that possess channels with well defined pores of 5 - 13 A. Zeolites based on aluminosilicates oxides present excellent thermal and chemical stability, and can be used efficiently as acid catalysts [39]. Among those, one of the solid catalysts types that were tested for furfural production was HZSM-5 Zeolite which is largely used in petrochemical engineering, bioengineering and environmental engineering due to its high catalytic activity, selectivity and stability. Chen (2015) [45] developed a new method of furfural production using the liquor obtained after steam explosion pretreatment of rice straw, using as acid solid catalyst HZSM-5 Zeolite. In order to improve process efficiency, it was added to the reaction mixture a polymerization inhibitor, 4-methoxyphenol, which improved conversion of rice straw liquor in furfural. Another study involving zeolites use as acid catalyst was developed by Gao (2014) [46], in which aqueous waste hemicelluloses solutions were used along with ZSM-5 zeolite, being proved the catalyst stability and the possibility of its reuse.

\section{Furfural Physical-Chemical Properties}

Furfural, whose chemical structure is shown in Figure 9, is a chemical similar to 5-hydroxymethylfurfural and derived from furan. This heterocyclic and aromatic aldehyde, whose molecular formula is $\mathrm{C}_{5} \mathrm{H}_{4} \mathrm{O}_{2}$, is also known as 2-furancarboxyaldehyde, furaldehyde, 2-furanaldehyde, fural and furfuraldehyde [11] [13].

Some of furfural physical properties are shown on Table 2. Excellent furfural physical properties make it a great selective extractant that can be used in aromatics removal from lubricant oils improving relationship between viscosity and temperature, aromatics removal from diesel to improve ignition properties, cross-linking in polymers and use as fungicide.

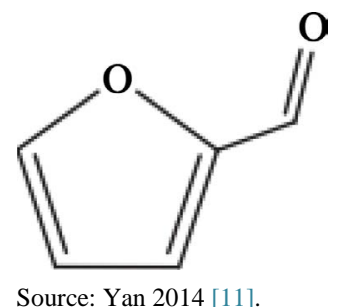

Figure 9. Furfural chemical structure.

Table 2. Furfural physical properties.

\begin{tabular}{cc} 
Furfural properties & \\
\hline Molecular weight & 96.08 \\
Boiling point $\left({ }^{\circ} \mathrm{C}\right)$ & 161.7 \\
Freezing point $\left({ }^{\circ} \mathrm{C}\right)$ & 36.5 \\
Density at $25^{\circ} \mathrm{C}$ & 1.16 \\
Refraction index at $25^{\circ} \mathrm{C}$ & 1.5235 \\
Critical pressure $(\mathrm{MPa})$ & 5.502 \\
Critical temperature $\left({ }^{\circ} \mathrm{C}\right)$ & 397 \\
Solubility in water at $25^{\circ} \mathrm{C}(\% \mathrm{peso})$ & 8.3 \\
Dielectric constant $20^{\circ} \mathrm{C}$ & 41.9 \\
Vaporization heat $(\mathrm{kJ} / \mathrm{mol})$ & 42.8 \\
Viscosity at $25^{\circ} \mathrm{C}(\mathrm{mPA})$ & 1.49 \\
Combustion heat at $25^{\circ} \mathrm{C}(\mathrm{kJ} / \mathrm{mol})$ & 234.4 \\
Formation enthalpy $(\mathrm{kJ} / \mathrm{mol})$ & 151 \\
Surface tension $29.9^{\circ} \mathrm{C}(\mathrm{mN} / \mathrm{m})$ & 40.7 \\
Auto-ignition temperature $\left({ }^{\circ} \mathrm{C}\right)$ & 315 \\
\hline
\end{tabular}

a. Source: Yan, 2014 [11]. 
Furfural has two important functional groups, an aldehyde $(\mathrm{CHO})$ and a conjugated system $(\mathrm{C}=\mathrm{C}-\mathrm{C}=\mathrm{C})$, it is a versatile compound for many applications (Figure 10). Furfural aldehyde group can undergo different types of reactions as acetylation, acylation, aldol and Knoevenagel condensation, reduction to alcohols, reductive amination to amines, decarboxylation, oxidation to carboxylic acids and Grignard reactions. The furan ring system $(\mathrm{C}=\mathrm{C}-\mathrm{C}=\mathrm{C})$ can undergo alkylation, hydrogenation, oxidation, halogenation, open ring reactions and nitration [11] [47].

\section{Applications of Furfural and Its Derivatives}

Furfural is derived from pentoses, more precisely from xylose, through a dehydration in acid medium. In this process, simultaneously it is obtained its methyl derivative 5-hydroxymethylfurfural, in smaller amount, and these compounds can be separated through distillation. This "impurity" from furfural production can be used as a flavor agent in fine chemical industry [48].

Furfural has several applications such as antacids, fertilizers, plastics, inks, fungicides, nematicides, adhesives and flavoring compounds [11] [12]. One of the different applications of furfural is on hydrocarbons purification technology of C4 and C5, which was developed during the II World War for butadiene fabrication in the United States for synthetic rubber production. Through extractive distillation with furfural, butadiene can be separated from other hydrocarbons C4 and C5 respectively [49] [50]. The main furfural derivatives and its applications are shown on Table 3.

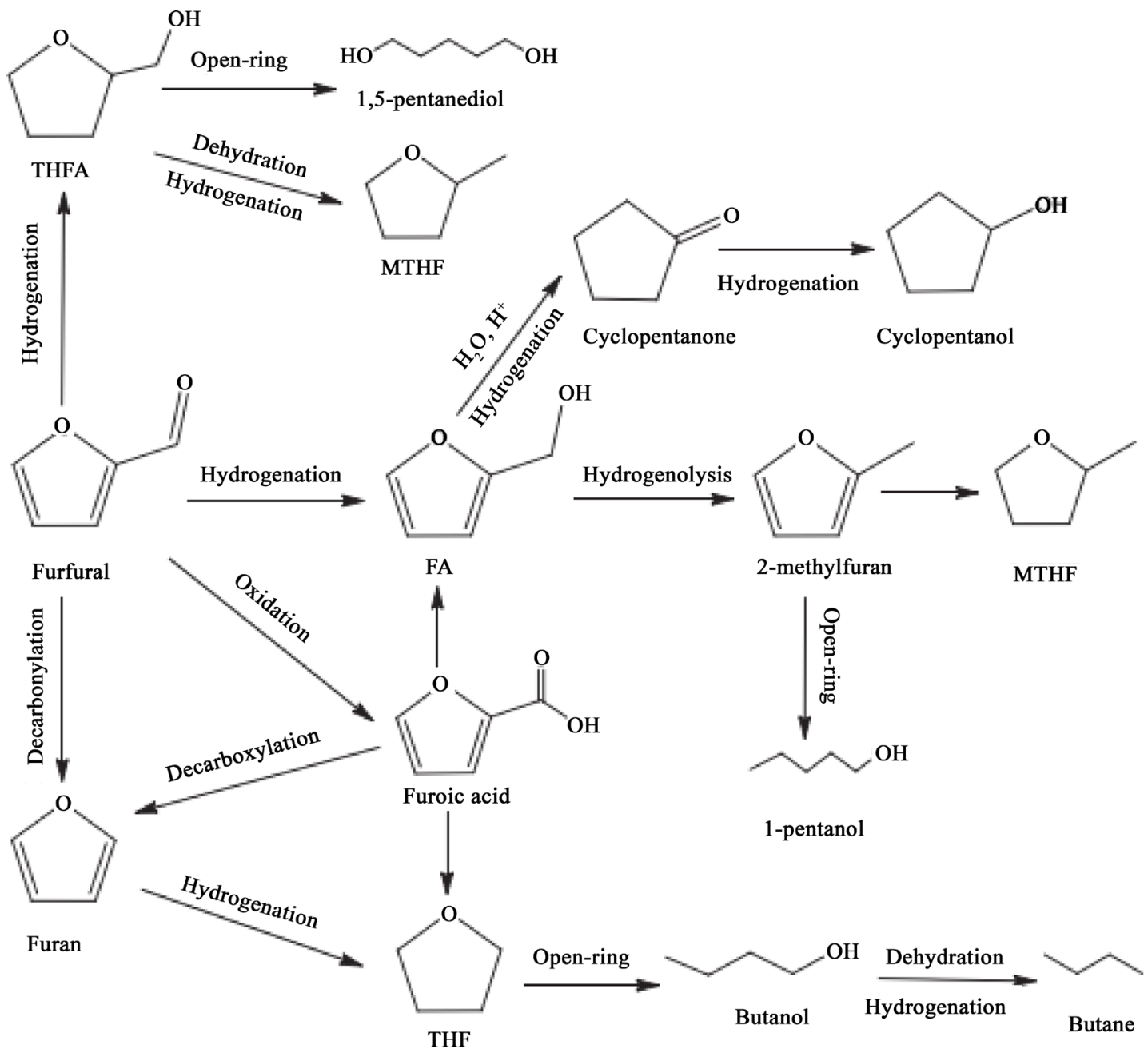

Source: Yan, 2014 [11].

Figure 10. Conversion of furfural into several high value added chemicals. 
Table 3. Furfural main derivatives.

\begin{tabular}{cll}
\hline Derivatives & \multicolumn{1}{c}{ Production } & \multicolumn{1}{c}{ Utilization } \\
\hline $\begin{array}{c}\text { Furfuryl alcohol } \\
\text { Furan }\end{array}$ & $\begin{array}{l}\text { Furfural catalytic hydrogenation } \\
\text { Furfural catalytic decarbonylation } \\
\text { Furfural and 5-methyl- furfural } \\
\text { decarbonylation }\end{array}$ & $\begin{array}{l}\text { Production of resins and tetrahydrofurfuryl alcohol; intermediate } \\
\text { in fragrances production, lysine and vitamin C } \\
\text { Production of tetrahydrofuran and acetylfuran }\end{array}$ \\
Tetrahydrofuran & Furan hydrogenation & Solvent and monomer \\
Furfurylamine & Furfural reductive amination & $\begin{array}{l}\text { Industrial solvent, polymers fabrication, adhesives, } \\
\text { pharmaceuticals products }\end{array}$ \\
Furoic acid & Furfural oxidation & $\begin{array}{l}\text { Production of substances with pharmacological and pesticide } \\
\text { activities }\end{array}$ \\
Levulinic acid & $\begin{array}{l}\text { Acid hydrolysis of furfuryl alcohol, } \\
\text { hydrolysis of acetyl succinate ester }\end{array}$ & Synthesis of medication and perfumes \\
Succinic acid & Alcoholic fermentation & Production of succinic acid and $\delta$-aminolevulinic acid \\
\hline
\end{tabular}

a. Source: Carmo, 2012, Ribeiro, 2012, Taylor, 2016 [13] [49] [51].

Resins produced from furfuryl acid have excellent thermal, chemical and physical properties, being resistant to corrosives and solvents action. Furfuryl acid also can used in plastics enforced with fibers manufacture, being recommended for high performance processes which involve chlorinated aromatics and oxygenated organic solvents [11] [52].

\section{Furfural Economic Aspects}

China concentrates the largest part of global furfural production, whose capacity is approximately 30 million tons per year. Low labor and feedstock costs, following increase in Chinese capacity of production, resulted in price drop over last decade. Furfural market price is approximately US\$1/kg, compared to US\$1.74/kg in 1990 and US\$ 1.76/kg of furfuryl alcohol. Europe and the United States increased rates of imports of furfural from China, to minimize the price difference, but market prices still depend on Chinese supply. A processing of 300 tons of biomass per day would produce approximately $1.3 \times 10^{7} \mathrm{~kg}$ of furfural per year. It represents $32.5 \%$ of total furfural/furfuryl alcohol consumption in Europe in 2000 [53] [54]. It stands out the annual revenue with the products, an additional R $\$ 69$ million relative to furfural sales, compared to a reduction of R $\$ 29$ million in the electricity revenue. An important aspect is furfural market price compared to electricity price, considering that both can be produced from the same feedstock, but in the two scenarios it was observed a cost reduction of $11 \%$ with furfural addition to the revenue [55].

In 2007, Brazil started importing furfural, because Rafard S.A. Agrochemicals owned by Rhodia Group which used to produce furfural from sugarcane bagasse was closed in 1990. The biggest market for furfural use was for furfuryl alcohol production, but now it is destined to lubricant oil refining [9].

The main producers, consumers and price of furfural in the world are shown on Table 4, Table 5 and Table 6 respectively.

\section{Final Considerations}

Biomass utilization for biomaterials, biochemicals, bioenergy and biofuels production has been vastly investigated due to economic, political and environmental concerns relating to finite reservation of non-renewable sources like petroleum. The development of production processes feasible in the industry of chemicals, biofuels, materials and energy from renewable sources as lignocellulosic biomass is extremely important. Lignocellulosic biomass is a feedstock highly advantageous for obtaining high value added products, because it has large availability and presents relatively low cost, and through strategies of biorefinery processes improvements, it is possible to obtain chemical products, such as furfural which can be used in different application, as in fine chemistry products, biofuels, additives among other high value added products.

Once furfural has many applications, understanding different methods of production of this chemical used vastly in the industry, as well as proposals for these processes improvements and new routes for value added 
Table 4. Furfural production in the world.

\begin{tabular}{ccc}
\hline Country & Feedstock & Production (ton/year) \\
\hline China & Corncob & 200,000 \\
Thailand & Corncob & 8500 \\
Dominican Republic & Bagasse & 32,000 \\
South Africa & Bagasse & 20,000 \\
Spain & Corncob & 6000 \\
Others (India \& South America) & Corncob/bagasse & $<15,000$ \\
Russia (used internally) & Corncob & - \\
Total & & $>280,000$ \\
\hline
\end{tabular}

a. Source: Win, 2005 [14].

Table 5. Furfural consumption in the world.

\begin{tabular}{cc}
\hline Country/Continent/Region & Furfural (t/year) \\
\hline Europe & 12,000 \\
United Stated & 8000 \\
Middle East & 7000 \\
Japan & 6000 \\
Taiwan Region & 5000 \\
South America & 5000 \\
Mainland China & 5000 \\
Australia/South Africa & 2000 \\
Others & Up to 50,000 \\
Total & $50,000-100,000$ \\
\hline
\end{tabular}

a. Source: Win, 2005 [14].

Table 6. Furfural price in the world between 1995-2002.

\begin{tabular}{ccc}
\hline Year & Price range $(\$ / t)$ & Comments \\
1995 & $675-1250$ & Drought in China \\
1996 & $840-1845$ & Drought in China \\
1997 & $860-1225$ & Drought in China \\
1998 & $830-990$ & \\
1999 & $690-865$ & \\
2000 & $630-705$ & \\
2001 & $>650$ & \\
2002 & $500-1100$ & \\
\hline
\end{tabular}

a. Source: Win, 2005 [14].

products production are important to reach the replacement of chemicals and materials from non-renewable sources by those obtained from renewable sources as lignocellulosic biomass.

Furfural is a carbon-based chemical which potentially can be used as an alternative to produce several products as paints, fertilizers, fuel additives and many others products that are normally produced from non-renewable resources. In this sense, it is important to invest in further researches aiming yield improvement of furfural production from lignocellulosic biomass and also investigate new catalysts to replace mineral acids which achieve acceptable yields and productivities, so that furfural production from lignocellulosic biomass become economically feasible and competitive. 


\section{References}

[1] Santos, F., Colodette, J. and Queiroz, J.H. (2013) Bioenergia e Biorrefinaria-Cana-de-Açúcar e Espécies Florestais. Viçosa.

[2] Alves, J.O. (2007) Eco-eficiência na produção de energia com biomassa de mamona: além do biodiesel. M.S. Thesis, Salvador University, Salvador.

[3] Ekpeni, L.E.N., Benyounis, K.Y., Nkem-Ekpeni, F., Stokes, J. and Olabi, A.G. (2014) Energy Diversity through Renewable Energy Source (RES)—A Case Study of Biomass. Energy Procedia, 61, 1740-1747. http://dx.doi.org/10.1016/j.egypro.2014.12.202

[4] Ministério De Minas e Energia (2014) Brasil é o $4^{\circ}$ país em produção de fontes renováveis de energia. MME WEBSITE.

http://www.mme.gov.br/web/guest/pagina-inicial/outras-noticas/-/asset_publisher/32hLrOzMKwWb/content/brasil-e-o -4-pais-em-producao-de-fontes-renovaveis-de-energia

[5] Petrobras. Produção de Biocombustíveis. http://www.petrobras.com.br/pt/nossas-atividades/areas-de-atuacao/producao-de-biocombustiveis

[6] Maity, S.K. (2015) Opportunities, Recent Trends and Challenges of Integrated Biorefinery: Part I. Renewable and Sustainable Energy Reviews, 43, 1427-1445. http://dx.doi.org/10.1016/j.rser.2014.11.092

[7] Neureiter, M., Danner, H., Thomasser, C., Aidi, B. and Braun, R. (2002) Dilute-Acid Hydrolysis of Sugarcane Bagasse at Varying Conditions. Applied Biochemistry and Biotechnology, 98, 49-58. http://dx.doi.org/10.1385/ABAB:98-100:1-9:49

[8] Banerjee, R. and Pandey, A. (2002) Bio-Industrial Application of Sugarcane Bagasse: A Technological Perspective. International Sugar Journal, 104, 64-70.

[9] Rodrigues, F.A. (2007) Avaliação da tecnologia de hidrólise ácida de bagaço de cana. M.S. Thesis, State University of Campinas, Campinas.

[10] Santos, F.A., Queiróz, J.H., Colodette, J.L., Fernandes, S.A., Guimarães, V.M. and Rezende, S.T. (2012) Potencial da palha de cana-de-açúcar para produção de etanol. Química Nova, 35, 1004-1010. http://dx.doi.org/10.1590/S0100-40422012000500025

[11] Yan, K., Wu, G., Lafleur, T. and Jarvis, C. (2014) Production, Properties and Catalytic Hydrogenation of Furfural to Fuel Additives and Value-Added Chemicals. Renewable and Sustainable Energy Reviews, 38, 663-676. http://dx.doi.org/10.1016/j.rser.2014.07.003

[12] Raman, J.K. and Gnansounou, E. (2015) Furfural Production from Empty Fruit Bunch—A Biorefinery Approach. Industrial Crops and Products, 69, 371-377. http://dx.doi.org/10.1016/j.indcrop.2015.02.063

[13] Ribeiro, P.R., Carvalho, J.R.M., Geris, R., Queiroz, V. and Fascio, M. (2012) Furfural—Da biomassa ao laboratório de química orgânica. Química Nova, 35, 1046-1051. http://dx.doi.org/10.1590/S0100-40422012000500033

[14] Win, D.T. (2005) Furfural-Gold from Garbage. AU Journal of Technology, 8, 185-190.

[15] Shittu, A.A. (2010) Catalytic Conversion of Hemicellulosic Sugars into Furfural in Ionic Liquid Media. M.S. Thesis, University of Toledo, Toledo.

[16] Dutta, S., De, S., Saha, B. and Alam, M.I. (2012) Advances in Conversion of Hemicellulosic Biomass to Furfural and Upgrading to Biofuels. Catalysis Science and Technology, 2, 2025-2036. http://dx.doi.org/10.1039/c2cy20235b

[17] Forster-Carneiro, T., Berni, M.D., Dorileo, I.L. and Rostagno, M.A. (2013) Biorefinery Study of Availability of Agriculture Residues and Wastes for Integrated Biorefineries in Brazil. Resources, Conservation and Recycling, 77, 78-88. http://dx.doi.org/10.1016/j.resconrec.2013.05.007

[18] Liu, L., Sun, J., Cai, C., Wang, S., Pei, H. and Zhang, J. (2009) Corn Stover Pretreatment by Inorganic Salts and Its Effects on Hemicellulose and Cellulose Degradation. Bioresource Technology, 100, 5865-5871. http://dx.doi.org/10.1016/j.biortech.2009.06.048

[19] Wondu Business and Technology Services (2006) Furfural Chemicals and Biofuels from Agriculture. Rural Industries Research and Development Corporation, 06/127, Sydney, 39.

[20] Montané, D., Salvadó, J., Torras, C. and Farriol, X. (2002) High-Temperature Dilute-Acid Hydrolysis of Olive Stones for Furfural Production. Biomass and Bioenergy, 22, 295-304. http://dx.doi.org/10.1016/S0961-9534(02)00007-7

[21] Eichler, P., Santos, F., Toledo, M., Zerbin, P., Schmitz, G., Alves, C., Ries, L. and Gomes, F. (2015) Produção do biometanol via gaseificação de biomassa lignocelulósica. Quimíca Nova, 38, 828-835.

[22] Phitsuwan, P., Sakka, K. and Ratanakhanokchai, K. (2013) Improvement of Lignocellulosic Biomass in Planta: A Review of Feedstocks, Biomass Recalcitrance, and Strategic Manipulation of Ideal Plants Designed for Ethanol Production And Processability. Biomass and Bioenergy, 58, 390-405. http://dx.doi.org/10.1016/j.biombioe.2013.08.027 
[23] Rambo, M.K.D., Schmidt, F.L. and Ferreira, M.M.C. (2015) Analysis of the Lignocellulosic Components of Biomass Residues for Biorefinery Opportunities. Talanta, 144, 696-703. http://dx.doi.org/10.1016/j.talanta.2015.06.045

[24] Yang, S.-T. and Yu, M. (2013) Bioprocessing Technologies in Biorefinery for Sustainable Production of Fuels, Chemicals, and Polymers. John Wiley \& Sons, New Jersey.

[25] Mabee, W.E., Mcfarlane, P.N. and Saddler, J.N. (2011) Biomass Availability for Lignocellulosic Ethanol Production. Biomass and Bioenergy, 35, 4519-4529. http://dx.doi.org/10.1016/j.biombioe.2011.06.026

[26] Mood, S.H., Golfeshan, A.H., Tabatabaei, M., Jouzani, G.S., Najafi, G.H., Gholamib, M. and Ardjmand, M. (2013) Lignocellulosic Biomass to Bioethanol, a Comprehensive Review with a Focus on Pretreatment. Renewable and Sustainable Energy Reviews, 27, 77-93. http://dx.doi.org/10.1016/j.rser.2013.06.033

[27] Santos, F.A., Queiroz, J.H., Colodette, J.L., Manfredi, M., Queiroz, M.E.L.R., Caldas, C.S. and Soares, F.E.F. (2014) Otimização do pré-tratamento hidrotérmico da palha de cana-de-açúcar visando à Produção de etanol celulósico. Química Nova, 37, 56-62. http://dx.doi.org/10.1590/S0100-40422014000100011

[28] Corbett, D.B., Kohan, N., Machado, G., Jing, C., Nagardeolekar, A. and Bujanovic, B. (2015) Chemical Composition of Apricot Pit Shells and Effect of Hot-Water Extraction. Energies, 8, 9640-9654. http://dx.doi.org/10.3390/en8099640

[29] Buckeridge, M.S., Santos, W.D. and Souza, A.P. (2010) As Rotas Para O Etanol Celulósico No Brasil. In: Cortez, L.A.B., Ed., Bioetanol de cana-de-açúcar: P\&D para Produtividade Sustentabilidade, Edgard Blücher, São Paulo, 365-380.

[30] Fitzpatrick, M., Champagne, P., Cunningham, M.F. and Whitney, R.A. (2010) A Biorefinery Processing Perspective: Treatment of Lignocellulosic Materials for the Production of Value-Added Products. Bioresource Technology, 101, 8915-8922. http://dx.doi.org/10.1016/j.biortech.2010.06.125

[31] Alvim, J.C., Alvim, F.A.L.S., Sales, V.H.G., Sales, P.V.G., Oliveira, E.M. and Costa, A.C.R. (2014) Biorrefinarias: Conceitos, classificação, matérias primas e produtos. Journal of Bioenergy and Food Science, 1, 61-77.

[32] Cheali, P., Posada, J.A., Gernaey, K.V. and Sin, G. (2015) Upgrading of Lignocellulosic Biorefinery to Value Added Chemicals: Sustainability and Economics of Bioethanol-Derivatives. Biomass and Bioenergy, 75, 282-300. http://dx.doi.org/10.1016/j.biombioe.2015.02.030

[33] Vaz Jr., S. (2011) Biorrefinarias: cenários e perspectivas. Embrapa Agroenergia, Brasília, DF.

[34] García, A., Alriols, M.G. and Labidi, J. (2014) Evaluation of Different Lignocellulosic Raw Materials as Potential Alternative Feedstocks in Biorefinery Processes. Industrial Crops and Products, 53, 102-110. http://dx.doi.org/10.1016/j.indcrop.2013.12.019

[35] Wang, W., Ren, J., Li, H., Deng, A. and Sun, R. (2015) Direct Transformation of Xylan-Type Hemicelluloses to Furfural via $\mathrm{SnCl}_{4}$ Catalysts in Aqueous and Biphasic Systems. Bioresource Technology, 183, 188-194. http://dx.doi.org/10.1016/j.biortech.2015.02.068

[36] Barbosa, B.M., Colodette, J.L., Longue Jr., D., Gomes, F.J.B. and Martino, D.C. (2014) Preliminary Studies on Furfural Production from Lignocellulosics. Journal of Wood Chemistry and Technology, 34, 178-190. http://dx.doi.org/10.1080/02773813.2013.844167

[37] Zhang, H., Liu, X., Lu, M., Hu, X., Lu, L., Tian, X. and Ji, J. (2014) Role of Brønsted Acid in Selective Production of Furfural in Biomass Pyrolysis. Bioresource Technology, 169, 800-803. http://dx.doi.org/10.1016/j.biortech.2014.07.053

[38] Mesa, L., Morales, M., González, E., Cara, C., Romero, I., Castro, E. and Mussatto, S.I. (2014) Restructuring the Processes for Furfural and Xylose Production from Sugarcane Bagasse in a Biorefinery Concept for Ethanol Production. Chemical Engineering and Processing, 85, 196-202. http://dx.doi.org/10.1016/j.cep.2014.07.012

[39] Agirrezabal-Telleria, I., Gandarias, I. and Arias, P.L. (2014) Heterogeneous Acid-Catalysts for the Production of Furan-Derived Compounds (Furfural and Hydroxymethylfurfural) from Renewable Carbohydrates: A Review. Catalysis Today, 234, 42-58. http://dx.doi.org/10.1016/j.cattod.2013.11.027

[40] Kaur, I. and Ni, Y. (2015) A Process to Produce Furfural and Acetic Acid from Pre-Hydrolysis Liquor of Kraft Based Dissolving Pulp Process. Separation and Purification Technology, 146, 121-126. http://dx.doi.org/10.1016/j.seppur.2015.03.034

[41] Baktash, M.M., Ahsan, L. and Ni, Y. (2015) Production of Furfural from an Industrial Pre-Hydrolysis Liquor. Separation and Purification Technology, 149, 407-412. http://dx.doi.org/10.1016/j.seppur.2015.06.003

[42] Li, H., Dai, Q., Ren, J., Jian, L., Peng, F., Sun, R. and Liu, G. (2016) Effect of Structural Characteristics of Corncob Hemicelluloses Fractionated by Graded Ethanol Precipitation on Furfural Production. Carbohydrate Polymers, 136, 203-209. http://dx.doi.org/10.1016/j.carbpol.2015.09.045

[43] Li, H., Ren, J., Zhong, L., Sun, R. and Liang, L. (2015) Production of Furfural from Xylose, Water-Insoluble Hemicelluloses and Water-Soluble Fraction of Corncob via a Tin-Loaded Montmorillonite Solid Acid Catalyst. Bioresource 
Technology, 176, 242-248. http://dx.doi.org/10.1016/j.biortech.2014.11.044

[44] Molina, M.J.C., Granados, M.L., Gervasini, A. and Carniti, P. (2015) Exploitment of Niobium Oxide Effective Acidity for Xylose Dehydration to Furfural. Catalysis Today, 254, 90-98. http://dx.doi.org/10.1016/j.cattod.2015.01.018

[45] Chen, H., Qin, L. and Yu, B. (2015) Furfural Production from Steam Explosion Liquor of Rice Straw by Solid Acid Catalysts (HZSM-5). Biomass and Bioenergy, 73, 77-83. http://dx.doi.org/10.1016/j.biombioe.2014.12.013

[46] Gao, H., Liu, H., Pang, B., Yu, G., Du, J., Zhang, Y., Wang, H. and Mu, X. (2014) Production of Furfural from Waste Aqueous Hemicellulose Solution of Hardwood over ZSM-5 Zeolite. Bioresource Technology, 172, 453-456. http://dx.doi.org/10.1016/j.biortech.2014.09.026

[47] Yan, K. and Chen, A. (2013) Efficient Hydrogenation of Biomass-Derived Furfural and Levulinic Acid on the Facilely Synthesized Noble-Metal-Free Cu-Cr Catalyst. Energy, 58, 357-363. http://dx.doi.org/10.1016/j.energy.2013.05.035

[48] Gomes, M.G. (2009) Síntese de poliésteres a partir do ácido 2,5-Furanodicarboxílico. M.S. Thesis, Aveiro University, Portugal.

[49] Carmo, C.B. (2013) Mapeamento tecnológico de polímeros furânicos a partir de biomassa. M.S. Thesis., Federal University of Rio de Janeiro, Rio de Janeiro.

[50] Xiu, S. and Shahbazi, A. (2012) Bio-Oil Production and Upgrading Research: A Review. Renewable and Sustainable Energy Reviews, 16, 4406-4414. http://dx.doi.org/10.1016/j.rser.2012.04.028

[51] Taylor, M.J., Durndell, L.J., Isaacs, M.A., Parlett, C.M.A., Wilson, K., Lee, A.F. and Kyriakou, G. (2016) Highly Selective Hydrogenation of Furfural over Supported Pt Nanoparticles under Mild Conditions. Applied Catalysis B: Environmental, 180, 580-585. http://dx.doi.org/10.1016/j.apcatb.2015.07.006

[52] Antunes, M.M., Lima, S., Neves, P., Magalhaes, A.L., Fazio, E., Neri, F., Pereira, M.T., Silva, A.F., Silva, C.M., Rocha, S.M., Pillinger, M., Urakawa, A. and Valente, A.A. (2016) Integrated Reduction and Acid-Catalysed Conversion of Furfural in Alcohol Medium Using Zr, Al-Containing Ordered Micro/Mesoporous Silicates. Applied Catalysis B, Environmental, 182, 485-503.

[53] Hayes, D.J., Ross, J., Hayes, M.H.B. and Fitzpatrick, S. (2008) The Biofine Process: Production of Levulinic Acid, Furfural and Formic Acid from Lignocellulosic Feedstocks. In: Biorefineries-Industrial Processes and Products: Status Quo and Future Directions, Wiley VCH, Weinheim.

[54] Bhogeswararao, S. and Srinivas, D. (2015) Catalytic Conversion of Furfural to Industrial Chemicals over Supported Pt and Pd Catalysts. Journal of Catalysis, 327, 65-77. http://dx.doi.org/10.1016/j.jcat.2015.04.018

[55] Silva, J.F.L., Selicani, M.A., Junqueira, T.L., et al. (2015) Integração da produção de furfural em uma biorrefinaria de cana-de-açúcar. São Paulo, Brasil. http://dx.doi.org/10.5151/chemeng-cobeqic2015-324-33923-264473 